ROCHA, RS; JAEGGI, MEPC; PEREIRA, IM; CRUZ, DP; SILVA, RKG; BATISTA, JN; SOUZA, AO; RODRIGUES, RR; GRAVINA, GA; LIMA, WL. 2021. Influence of spacing and harvests on the production of scarlet eggplant and chicory under intercropping system. Horticultura Brasileira 39: 216222. Doi: http://dx.doi.org/10.1590/s0102-0536-20210213

\title{
Influence of spacing and harvests on the production of scarlet eggplant and chicory under intercropping system
}

\author{
Richardson S Rocha ${ }^{1} \mathbb{D}$; Mário Euclides PC Jaeggi ${ }^{1} \mathbb{D}$; Israel M Pereira ${ }^{1} \mathbb{D}$; Derivaldo P da Cruz ${ }^{1} \mathbb{D}$; Rita \\ de Kássia G da Silva ${ }^{1} \mathbb{D}$; Josimar N Batista ${ }^{1} \mathbb{D}$; André O Souza ${ }^{2} \mathbb{D}$; Rogério R Rodrigues ${ }^{3} \mathbb{D}$; Geraldo de A \\ Gravina ${ }^{1} \mathbb{D}$; Wallace Luís de Lima ${ }^{2 \mathbb{D}}$
}

${ }^{1}$ Universidade Estadual do Norte Fluminense (UENF), Campos dos Goytacazes-RJ, Brasil; richardson_sales@hotmail.com; mariopechara@ hotmail.com; israelmartins80@gmail.com; deri.engineer@gmail.com; kassiaguarnier@gmail.com; josimarbatista.agro@gmail.com; gravina@uenf.br; ${ }^{2}$ Instituto Federal do Espírito Santo (IFES), Alegre-ES, Brasil; andre.souza@ifes.edu.br; limawl@yahoo.com.br; ${ }^{3}$ Instituto Federal de Educação, Ciência e Tecnologia do Pará (IFPA), Belém-PA, Brasil; rogeriorr7@hotmail.com

\begin{abstract}
The aim of this study was to evaluate the fresh mass of scarlet eggplant $(\mathrm{kg} / \mathrm{pl})$ and the number of leaves of chicory $\left(\mathrm{n}^{\circ} \mathrm{f} / \mathrm{pl}\right)$ in relation to the spacing used by the farmers of the region for both crops. The experiment evaluated these crops under intercropping cultivation system, varying the number of chicory rows between scarlet eggplant rows as well as harvests (cycle of each crop), for intercropping and monocropping systems. The treatments were $\mathrm{T} 1=$ scarlet eggplant $0.7 \times 1.1 \mathrm{~m}$ (monocropping); $\mathrm{T} 2=$ intercropped scarlet eggplant, $0.7 \times 1.5 \mathrm{~m}$, with four rows of chicory, $0.2 \times 0.2 \mathrm{~m}$ between rows; $\mathrm{T} 3=$ intercropped scarlet eggplant, $0.7 \times 1.1 \mathrm{~m}$, with three rows and chicory, $0.2 \times 0.2 \mathrm{~m}$; T4= intercropped scarlet eggplant, $0.7 \times 1.3$ $\mathrm{m}$, with four rows of chicory, $0.2 \times 0.2 \mathrm{~m}$; $\mathrm{T} 5=$ intercropped scarlet eggplant, $0.7 \times 1.3 \mathrm{~m}$, with three rows of chicory, $0.2 \times 0.2 \mathrm{~m}$; $\mathrm{T} 6=$ chicory $0.2 \times 0.1 \times 0.4 \mathrm{~m}$ in two double rows, $0.2 \mathrm{~m}$ between rows, 0.1 $\mathrm{m}$ between plants and $0.4 \mathrm{~m}$ between double rows in $1.5 \mathrm{~m}$ linear area (monocropping) and $\mathrm{T} 7=$ chicory $0.2 \mathrm{x} 0.3 \mathrm{~m}$ with three simple rows in an $1.5-\mathrm{m}$ area (monocropping). The experimental design was of strip blocks, in a 5x16 factorial scheme, consisting of five spacings of scarlet eggplant (monocropping), $1.5 \times 0.7 \mathrm{~m}, 1.3 \times 0.7$ $\mathrm{m}$ and $1.1 \mathrm{x} 0.7 \mathrm{~m}$, alternating the number of chicory rows between rows and 16 harvests in time, once a week. For chicory, the design was also in a $6 \times 12$ factorial scheme, with six spacings. The spacing $0.2 \times 0.2 \mathrm{~m}$ was intercropped with scarlet eggplant, alternating the number of rows and two monocroppings $0.2 \times 0.1 \times 0.4 \mathrm{~m}$ in double rows and $0.2 \times 0.3 \mathrm{~m}$ with 12 harvests in time, being performed one harvest per week along with the scarlet eggplant. Intercropped scarlet eggplant in spacing $0.7 \times 1.5 \mathrm{~m}$ showed higher averages in some harvests followed by spacing $0.7 \times 1.3 \mathrm{~m}$ with four chicory rows between rows. Spacings $0.2 \times 0.1 \times 0.4 \mathrm{~m}$ and $0.2 \times 0.3 \mathrm{~m}$ were the ones which provided the best averages for chicory crop, except for the $5^{\text {th }}$ harvest, in which spacing $0.2 \times 0.2 \mathrm{~m}$ consisting of four chicory rows provided the highest average (5.7 leaves/plant). Regardless of monocropping and intercropping arrangement used for chicory the Area Equivalence Index (IEA) was over 1.6.
\end{abstract}

Keywords: Solanum gilo, Cichorium intybus, intercropping.

\section{RESUMO}

Influência do espaçamento e colheitas na produção do jiló e almeirão sob cultivo consorciado

O objetivo do presente trabalho foi avaliar a massa fresca do jiló ( $\mathrm{kg} / \mathrm{pl})$ e número de folhas de almeirão $\left(\mathrm{n}^{\circ} \mathrm{f} / \mathrm{pl}\right)$ em função dos espaçamentos usuais pelos agricultures da região para ambas as culturas em sistema consorciado variando o número de linhas de almeirão na entrelinha do jiló e, colheitas (ciclo de cada cultura), para os consórcios e monocultivos. Os tratamentos foram $\mathrm{T} 1=$ jiló $0,7 \mathrm{x} 1,1$ $\mathrm{m}$ (monocultivo); $\mathrm{T} 2=$ consórcio de jiló, espaçamento de $0,7 \times 1,5$ $\mathrm{m}$, com quatro filas de almeirão, $0,2 \times 0,2 \mathrm{~m}$, nas entrelinhas; $\mathrm{T} 3=$ consórcio de jiló, $0,7 \times 1,1 \mathrm{~m}$, com três filas e almeirão, $0,2 \times 0,2 \mathrm{~m}$; T4= consórcio de jiló, $0,7 \times 1,3 \mathrm{~m}$, com quatro filas de almeirão, $0,2 \times 0,2 \mathrm{~m}$; T5= consórcio de jiló, $0,7 \times 1,3 \mathrm{~m}$, com três filas de almeirão, $0,2 \times 0,2$ $\mathrm{m}$; T6= almeirão $0,2 \mathrm{x} 0,1 \mathrm{x} 0,4 \mathrm{~m}$ em duas filas duplas com $0,2 \mathrm{~m}$ entre linhas, $0,1 \mathrm{~m}$ entre plantas e $0,4 \mathrm{~m}$ entre filas duplas sobre $1,5 \mathrm{~m}$ linear de área (monocultivo) e T7=almeirão $0,2 \times 0,3 \mathrm{~m}$ com três filas simples sobre 1,5 $\mathrm{m}$ de área (monocultivo). O delineamento foi em faixa, em um fatorial $5 \times 16$, contendo cinco espaçamentos de jiló de forma isolada, sendo $1,5 \times 0,7 \mathrm{~m}, 1,3 \times 0,7 \mathrm{~m}$ e 1,1x0,7 m, alternando-se o número de linhas de almeirão na entrelinha e 16 colheitas no tempo, sendo realizada uma por semana. Para o almeirão, o delineamento também foi em faixa em um fatorial $6 \times 12$, com seis espaçamentos. $\mathrm{O}$ espaçamento de $0,2 \times 0,2 \mathrm{~m}$ foi consorciado com jiló, alternando-se o número de linhas e dois monocultivos $0,2 \times 0,1 \times 0,4 \mathrm{~m}$ em filas duplas e $0,2 \times 0,3 \mathrm{~m}$ com 12 colheitas no tempo, sendo realizada uma por semana juntamente com o jiló. O jiló em consórcio no espaçamento de $0,7 \times 1,5 \mathrm{~m}$ apresentou maiores médias em algumas colheitas seguido do espaçamento de $0,7 \times 1,3 \mathrm{~m}$ com quatro filas de almeirão na entrelinha. Os espaçamentos $0,2 \times 0,1 \times 0,4 \mathrm{~m}$ e $0,2 \times 0,3 \mathrm{~m}$ foram os que proporcionaram as melhores médias para a cultura do almeirão, com exceção para a $5^{\circ}$ colheita, em que o espaçamento $0,2 \times 0,2 \mathrm{~m}$ com quatro filas de almeirão proporcionou a maior média ( 5.7 folhas/ planta). Independente do monocultivo e arranjo de consórcio utilizado para almeirão o IEA foi superior a 1.6.

Palavras-chave: Solanum gilo, Cichorium intybus, consórcio.

Received on December 18, 2020; accepted on April 6, 2021 
$\mathrm{H}$ orticultural production is a massive activity concerning the use of resources, such as soil, water and nutrients. The production needs high investments per unit of planted area, intercropping system can be an interesting option, though (Puiatti et al., 2015).

Among the challenges for a successful intercropping cultivation, besides the management adopted, selecting appropriate crops is essential. The effectiveness of intercropping largely depends on competitiveness between the crops, in order to reduce the negative effects between the growing plants; this is the reason why a criterious choice of crops to be cultivated is fundamental, in order to increase economic yield (Lopes \& Lima, 2015). Concerning the above, chicory and scarlet eggplant intercropping tends to show a variation in relation to cultural practices. The available resources and the production of scarlet eggplant and chicory under intercropping system undergo changes depending on adopted spacing. Studies on spacings between rows with harvest time were not found in literature.

Variations between harvests can be related to shading rate or due to the maximum competition between plants for soil nutrients, being verified a decrease in the following harvest. In some crops, plants, such as scarlet eggplant and chicory, demand some time to recover, videlicet, two or three weeks until the following harvest. Thus, the choice of spacing varied according to that used by farmers in the region. The most used spacing was $0.7 \times 1.1 \mathrm{~m}$ for monocropped scarlet eggplant. In general, spacing for scarlet eggplant cultivation ranged from 1.1 to $1.5 \mathrm{~m}$ between rows in intercropping cultivations in the region. For chicory, many growers use $0.2 \times 0.2$ and $0.2 \times 0.3 \mathrm{~m}$ spacing in monocropping and intercropping, respectively. Using larger spacing between lines, each plant has more space and can develop better. On the other hand, in intercropping, the productivity of number of leaves per area tends to be reduced.

Thus, the Area Equivalence Index
(IEA) is an important parameter to be used in order to check the efficiency of intercropping system when compared with monocropping. Intercropping becomes efficient when IEA is equal or superior to 1.0 and not efficient when IEA is lower than 1.0. Nevertheless, values superior to 1.0 show a higher yield for intercropping cultivation (Montezano \& Peil, 2006).

In literature, studies on intercropping between vegetables, which show agronomic performance superior to monocropping, are easy to find. Moreover, this practice is considered an economic practice and efficient in relation to soil use (Brito et al., 2017). Considering the studies carried out, we can mention: chicory with roquette (Cecílio Filho et al., 2008); lettuce with roquette (Costa et al., 2007); cucumber with roquette (Rezende, 2016); carrot with roquette (Lima, 2008); onion with lettuce (Paula et al., 2009); broccoli with lettuce (Ohse et al., 2012); taro with broccoli (Brito et al., 2017); taro with chinese cabbage (Brito et al., 2017) and taro with eggplant (Brito et al., 2017).

Chicory (Cichorium intybus) is a leaf vegetable, belonging to Asteraceae family, scarlet eggplant (Solanum aethiopicum $g r$. Gilo) belongs to Solanaceae family, with green fruits; however, both have pronounced bitter taste, presenting nutritional and pharmacological properties (Franco, 1987). We highlight that both crops present large-scale production per unit area and a high demand for labor (Heredia Zárate et al., 2009). These crops are characterized by a lowcost production and for being lowdemanding concernig soil fertility and inputs (Heredia Zárate et al., 2009).

Given the above, the aim of this study was to evaluate the fresh mass of scarlet eggplant $(\mathrm{kg} / \mathrm{pl})$ and number of leaves of chicory per plant $\left(n^{\circ} \mathrm{f} /\right.$ $\mathrm{pl)}$ in relation to spacings used by growers in the South Region of Espírito Santo for both crops in intercropping system varying the number of rows of chicory and between the rows of scarlet eggplant, as well as, harvests (cycle of each crop) for intercropping and monocropping systems.

\section{MATERIAL AND METHODS}

The experiment was carried out at Setor de Agroecologia at Instituto Federal do Espírito Santo (IFES), Alegre campus $\left(20^{\circ} 44^{\prime} 05^{\prime} \mathrm{S}, 41^{\circ} 25^{\prime} 50^{\prime} \mathrm{W}\right.$, $134 \mathrm{~m}$ altitude). According to Köppen classification, the local climate is Cwa, hot, under humid tropical conditions, with cold dry winter and hot rainy summer, $23.1^{\circ} \mathrm{C}$ average temperature and $1,341 \mathrm{~mm}$ total average rainfall.

In order to produce seedlings of Tingua Verde Claro (scarlet eggplant variety), the authors used 200 -mL plastic cups (white polyethylene) and, fifteen days after plant emergence (March $5^{\text {th }}$, 2017), the plants were thinned, leaving just one seedling per cup. Chicory and scarlet eggplant were allocated in a joint field experiment, being each of them studied as monocropped and intercropped cultivations, completing 7 spatial arrangements, considering $\mathrm{T} 1=$ scarlet eggplant $0.7 \times 1.1 \mathrm{~m}$ (monocropping); T2= intercropped scarlet eggplant, spacing $0.7 \times 1.5 \mathrm{~m}$, with four rows of chicory, $0.2 \times 0.2$ $\mathrm{m}$, between rows (Figure 1A); $\mathrm{T} 3=$ intercropped scarlet eggplant, $0.7 \times 1.1$ $\mathrm{m}$, with three rows of chicory, $0.2 \times 0.2$ m; T4= intercropped scarlet eggplant, $0.7 \times 1.3 \mathrm{~m}$, with four rows of chicory, $0.2 \times 0.2 \mathrm{~m} ; \mathrm{T} 5=$ intercropped scarlet eggplant, $0.7 \times 1.3 \mathrm{~m}$, with three rows of chicory, $0.2 \times 0.2 \mathrm{~m}$; $\mathrm{T} 6=$ chicory $0.2 \times 0.1 \times 0.4 \mathrm{~m}$ in two double rows with $0.2 \mathrm{~m}$ between rows, $0.1 \mathrm{~m}$ between plants and $0.4 \mathrm{~m}$ between double rows on an $1.5 \mathrm{~m}$ linear area (monocropping) (Figure 1B); and T7 = chicory $0.2 \times 0.3 \mathrm{~m}$ with three simple rows in an $1.5 \mathrm{~m}$ linear area (monocropping). All intercropped crops can be seen in Figure 1A.

The scarlet eggplant plants were sown in two rows, and each treatment consisted of four plants per row. The first and last plants of each treatment were discarded as borders. That means, each scarlet eggplant treatment consisted of four useful plants to be evaluated. Chicory was planted between these two rows of scarlet eggplant, considering the central rows of chicory as useful area. For monocropped chicory, we discarded 0.25 linear meters at the beginning and 
the end of the row as a border.

Japanese chicory was sown in 200 cells polyethylene trays, and 15 days after germination, the seedlings were transplanted to seedbeds (April $\left.5^{\text {th }}, 2017\right)$, putting just one seedling per pit. The harvests were evaluated as a factor to show variation between harvests. So, for a field trial evaluation, the experimental design was a stripplot, due to the harvests which were performed in time in a 5x16 factorial scheme, consisting of 5 treatments, which are the usual spacing used by growers in that region, $1.5 \times 0.7 \mathrm{~m}$, $1.3 \times 0.7 \mathrm{~m}$ and $1.1 \times 0.7 \mathrm{~m}$. We performed 16 harvests, once a week, throughout the scarlet eggplant reproductive cycle with four replicates. For chicory, we performed 6x12 factorial scheme with six treatments, with spacings $0.2 \times 0.2$ $\mathrm{m}$ and $0.2 \times 0.3 \mathrm{~m}$ and 12 harvests, performed once a week, troughout the chicory cycle, with four replicates, according to the following statistic model:

$$
\begin{aligned}
& y_{i j k}=\mu+\beta_{j}+\alpha_{i}+\varepsilon_{i j}+\gamma_{k}+\varepsilon_{j k}+ \\
& (\alpha \gamma)_{i j}+\varepsilon_{i j k} \text { onde } \varepsilon_{i j k} \sim N D\left(0, \sigma^{2}\right)
\end{aligned}
$$

in which: $y_{i j k}$ is the value of the $i-t h$ treatment $\mathrm{A}$ and $\mathrm{k}$-th treatment $\mathrm{B}$ in $\mathrm{j}$-th block; $\mu$ is the general constant of the model (usually average); $\beta \mathrm{j}$ is the effect of $j$-th block; $\alpha_{i}$ is the effect of $\mathrm{i}$-th treatment $\mathrm{A} ; \varepsilon_{\mathrm{jk}}$ is the experimental error between i-th level of factor $A$ and $\mathrm{j}$-th block; $\gamma_{\mathrm{k}}$ is the effect of the $\mathrm{k}$-th level of factor $B ; \varepsilon_{j k}$ is the experimental error between the $\mathrm{k}$-th level of factor $\mathrm{B}$ and $\mathrm{j}$-th block; $(\alpha \gamma)_{\mathrm{ij}}$ is the effect of the interaction between the $\mathrm{i}$-th level of factor A and the k-th level of factor B; $\varepsilon_{\mathrm{ijk}}$ is the experimental error between $\mathrm{i}$-th level of factor $A$ and $k$-th level of factor $B$ in the $\mathrm{j}$-th block.

According to Brazilian Soil Classification System (EMBRAPA, 1999), the soil was classified as RedYellow Latosol, with rugged topography. The field was plowed, harrowed and seedbeds were built with the aid of a seedbed tiller.

No specific fertilization management was performed for the crops, due to the difficulty in differentiating doses. Moreover, the experiment was implanted in a transitional agroecological area, where organic fertilization management is carried out whenever necessary. For that, we consider that the levels of each essential nutrient for the plants, especially vegetables, are present in soil, as well as organic matter content. For organic fertilizers, we used cattle manure, bean straw, corn straw, tree leaves, among others.

The soil used in the experiment showed the following contents: $\mathrm{MO}=$ $14 \mathrm{~g} / \mathrm{dm}^{3}, \mathrm{pH}=5.8, \mathrm{P}=34.2 \mathrm{mg} / \mathrm{dm}^{3}, \mathrm{~K}=$ $72 \mathrm{mg} / \mathrm{dm}^{3}, \mathrm{Ca}=2.6 \mathrm{cmol} / \mathrm{dm}^{3}, \mathrm{Mg}=0.8$ $\mathrm{cmol} / \mathrm{dm}^{3}, \mathrm{Al}=0.18 \mathrm{cmol} / \mathrm{dm}^{3}, \mathrm{H}+\mathrm{Al}=$ $5.30 \mathrm{cmol} / \mathrm{dm}^{3}, \mathrm{SB}=4.58 \mathrm{cmol} / \mathrm{dm}^{3}$, $\mathrm{CTC}=8.88 \mathrm{cmol} / \mathrm{dm}^{3}, \mathrm{~V}=50 \%, \mathrm{~K}=2 \%$ on the CTC, P-rem $=32.7 \mathrm{mg} / \mathrm{L}$, monoic $\mathrm{S}=20 \mathrm{mg} / \mathrm{dm}^{3}, \mathrm{~B}=0.60 \mathrm{mg} / \mathrm{dm}^{3}, \mathrm{Zn}=$ $1.2 \mathrm{mg} / \mathrm{dm}^{3}, \mathrm{Mn}=1.1 \mathrm{mg} / \mathrm{dm}^{3}, \mathrm{Cu}=0.3$ $\mathrm{mg} / \mathrm{dm}^{3}, \mathrm{Fe}=1.2 \mathrm{mg} / \mathrm{dm}^{3}$. Sprinkler irrigation was performed, using daily irrigation shifts to meet the demand during the crop cycle. Weed control was done with the aid of hoes between rows and hand plucking between plants.

Scarlet eggplant harvest began on May $5^{\text {th }} 2017$, being the green fruits harvested weekly, throughout the crop cycle, until September $5^{\text {th }}, 2017$, with 16 harvests, measuring fresh mass of fruits per plant $(\mathrm{kg} / \mathrm{pl})$. Chicory harvest began on May $10^{\text {th }}, 2017$, being the green leaves harvested once a week throughout the crop cycle, until Agust 10 ${ }^{\text {th }}, 2017$, with 12 harvests. The harvests of scarlet eggplant and chicory were always performed in the same plants. We used as an evaluation criterion, the way scarlet eggplant and chicory are commercialized in the markets of the region. Generally, scarlet eggplant is sold by weight of fruit $(\mathrm{kg} /$ $\mathrm{pl}$ ), chicory is sold by (moles) of leaves.

Chicory was harvested when leaves were 20 to $30 \mathrm{~cm}$ long; it shall not be less, or more, since leaves smaller than $20 \mathrm{~cm}$ are considered too fragile to be transported. Moreover, the small leaves do not meet the demand. Leaves larger than $30 \mathrm{~cm}$, present bitterness characteristics, and are considered old for consumption.

To calculate the Area Equivalence Index (IEA), we used the following formula:

$$
I E A=\frac{C A}{M A}+\frac{C I}{M}
$$

in which: CA represents the productivity of intercropped scarlet eggplant ( $\mathrm{kg} / \mathrm{ha})$; MA is the productivity of monocropped scarlet eggplant $(\mathrm{kg} / \mathrm{ha})$; CB represents the productivity of intercropped chicory ( $\mathrm{n}^{\mathrm{o}} \mathrm{f} / \mathrm{ha}$ ) and $\mathrm{MB}$ is the productivity of monocropped chicory ( $\left.\mathrm{n}^{\circ} \mathrm{f} / \mathrm{ha}\right)$.

Data were statistically analyzed using variance analysis ( $F$ test) and average test (Tukey), unfolding the spacing in each harvest of scarlet eggplant and chicory separately. The harvests were unfolded in each spacing to study the regression adjustments.

\section{RESULTS AND DISCUSSION}

The authors verified interaction among the spacings used in the experiment and harvests for the evaluated traits $(p<0.05)$. Both for fresh mass of scarlet eggplant $(\mathrm{kg} / \mathrm{pl})$ and for number of chicory leaves $\left(n^{\circ} \mathrm{f} /\right.$ $\mathrm{pl})$ variation coefficient $(\mathrm{CV})$ was above $40 \%$, showing reasonable experimental accuracy, considering that the variation between harvests is difficult to control. Moreover, environmental influence on harvests for both crops is related to "non-randomization in time", so that a strip-plot design was used.

Another important factor concerning this variation might have been the unevenness of water supply, since the sprinkler irrigation was not $100 \%$ uniform. Thus, even showing a high variation coefficient, the authors could verify differences among the spacings between rows. There exist very few studies in literature about variation between spacings on horticultural crops. Minami et al. (1998) reported no significant difference for spacings between rows of radish, even showing a lower CV compared to this study.

No significant difference for spacings in harvests $1^{\text {st }}, 3^{\text {rd }}, 4^{\text {th }}, 6^{\text {th }}, 7^{\text {th }}, 9^{\text {th }}, 10^{\text {th }}$, $12^{\text {th }}, 14^{\text {th }}, 15^{\text {th }}$ and $16^{\text {th }}$ for fresh mass of scarlet eggplant $(\mathrm{kg} / \mathrm{pl})$ (Table 1) was noticed. Intercropped scarlet eggplant in spacing $0.7 \times 1.5 \mathrm{~m}$ showed higher averages in some harvests followed by spacing $0.7 \times 1.3 \mathrm{~m}$, both consisting of four rows of chicory between rows.

Spacings used for chicory did not differ among each other during the first harvests, $1^{\text {st }}, 2^{\text {nd }}$ and $3^{\text {th }}$ (Table 2). Monocropping with a lower number 
of plants per hectare showed higher averages of leaf production per plant when compared with other treatments, except for the $5^{\text {th }}$ harvest, in which the spacing $0.2 \times 0.2 \mathrm{~m}$ with four rows of chicory provided the highest average, 5.7 leaves/plant.

When spacing between rows and plants is smaller, the microclimate formed induces a better use of the water resource in the place, avoiding evapotranspiration, increasing productivity (Minami et al.,1998). The same authors reported that a better efficiency in nutrient uptake is noticed when these nutrients are widely available in soil and when the competition between plants, for area, is lower.

Some studies report that plants under lower competition in the row, produce more and are able to accumulate higher quantity of photosynthesized reserves. Plant biomass shows that larger spacings in the row stimulate photosynthetic activity (Correa et al., 2014). Purquerio et al. (2007), working with roquette, verified that spacings over $0.5 \mathrm{~m}$ between plants provided satisfactory production since no standardization for this crop, and also for chicory, which makes it possible to classify the leaf size, obtained in different spacings, was reported.

The authors highlight that due to a smaller spacing had been superior to the

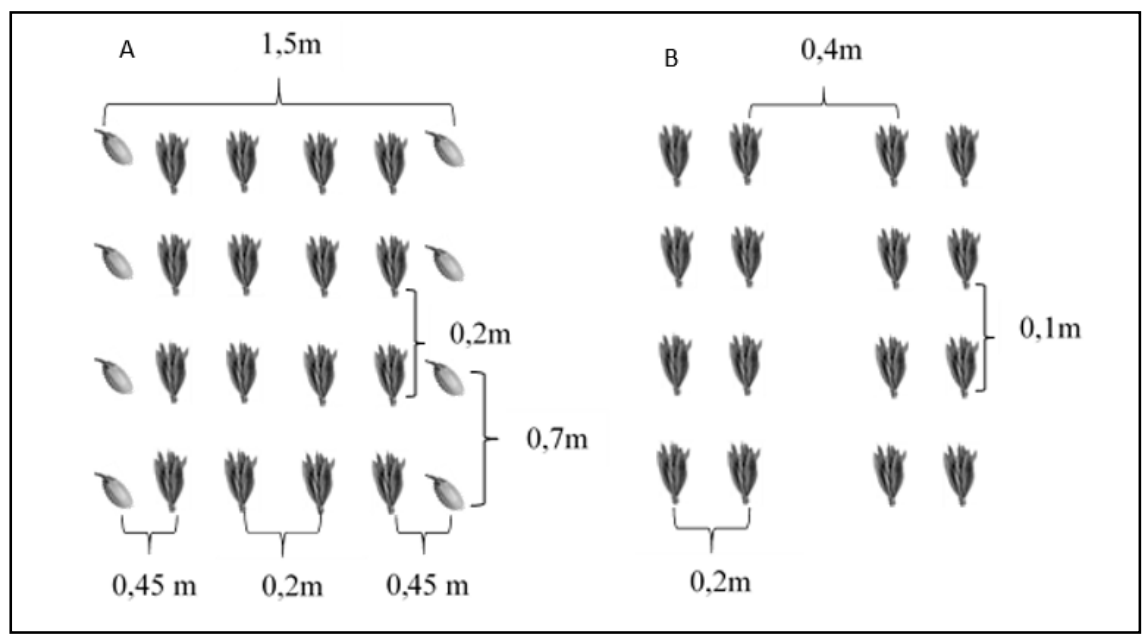

Figure 1. (A) intercropped scarlet eggplant, spacing $0.7 \times 1.5 \mathrm{~m}$, with four rows of chicory, $0.2 \times 0.2 \mathrm{~m}$ between rows related to T2 and (B) monocropped chicory in double rows, $0.2 \times 0.1 \times 0.4 \mathrm{~m}$ with $0.2 \mathrm{~m}$ between rows, $0.1 \mathrm{~m}$ between plants and $0.4 \mathrm{~m}$ between double rows related to T6. Alegre, IFES, 2018.

Table 1. Comparison of averages for fresh mass of scarlet eggplant $(\mathrm{kg} / \mathrm{pl})$, unfolding of spacings between lines for each harvest under intercropping system using chicory crop. Alegre, IFES, 2018.

\begin{tabular}{|c|c|c|c|c|c|c|c|c|c|c|c|c|c|c|c|c|}
\hline \multirow{2}{*}{ Treatments } & \multicolumn{16}{|c|}{ Harvests } \\
\hline & $1^{\text {st }}$ & $2^{\text {nd }}$ & $3^{\text {rd }}$ & $4^{\text {th }}$ & $5^{\text {th }}$ & $6^{\text {th }}$ & $7^{\text {th }}$ & $8^{\text {th }}$ & $9^{\text {th }}$ & $10^{\text {th }}$ & $11^{\text {th }}$ & $12^{\text {th }}$ & $13^{\text {th }}$ & $14^{\text {th }}$ & $15^{\text {th }}$ & $16^{\text {th }}$ \\
\hline 1 & $0.04 \mathrm{a}$ & $0.31 \mathrm{a}$ & $0.05 a$ & $0.10 \mathrm{a}$ & $0.69 \mathrm{a}$ & $0.16 \mathrm{a}$ & $0.07 \mathrm{a}$ & $0.42 \mathrm{a}$ & $0.13 \mathrm{a}$ & $0.29 a$ & $0.42 \mathrm{a}$ & $0.13 a$ & $0.45 \mathrm{a}$ & $0.17 \mathrm{a}$ & $0.13 \mathrm{a}$ & $0.14 \mathrm{a}$ \\
\hline 2 & $0.12 \mathrm{a}$ & $0.21 \mathrm{ab}$ & $0.08 \mathrm{a}$ & $0.22 \mathrm{a}$ & $0.59 \mathrm{ab}$ & $0.28 \mathrm{a}$ & $0.24 \mathrm{a}$ & $0.34 \mathrm{ab}$ & $0.30 \mathrm{a}$ & $0.28 \mathrm{a}$ & $0.39 \mathrm{a}$ & $0.20 \mathrm{a}$ & $0.41 \mathrm{a}$ & $0.32 \mathrm{a}$ & $0.17 \mathrm{a}$ & $0.33 \mathrm{a}$ \\
\hline 3 & $0.11 \mathrm{a}$ & $0.11 \mathrm{ab}$ & $0.11 \mathrm{a}$ & $0.20 \mathrm{a}$ & $0.44 b c$ & $0.26 \mathrm{a}$ & $0.14 \mathrm{a}$ & $0.29 \mathrm{ab}$ & $0.24 \mathrm{a}$ & $0.25 \mathrm{a}$ & $0.34 \mathrm{ab}$ & $0.25 \mathrm{a}$ & $0.29 \mathrm{ab}$ & $0.27 \mathrm{a}$ & $0.17 \mathrm{a}$ & $0.18 \mathrm{a}$ \\
\hline 4 & $0.05 \mathrm{a}$ & $0.07 \mathrm{~b}$ & $0.17 \mathrm{a}$ & $0.30 \mathrm{a}$ & $0.33 \mathrm{~cd}$ & $0.40 \mathrm{a}$ & $0.19 \mathrm{a}$ & $0.27 \mathrm{ab}$ & $0.25 \mathrm{a}$ & $0.12 \mathrm{a}$ & $0.26 \mathrm{ab}$ & $0.35 a$ & $0.28 \mathrm{ab}$ & $0.39 a$ & $0.25 a$ & $0.33 \mathrm{a}$ \\
\hline 5 & $0.09 \mathrm{a}$ & $0.05 b$ & $0.17 \mathrm{a}$ & $0.29 \mathrm{a}$ & $0.20 \mathrm{~d}$ & $0.33 \mathrm{a}$ & $0.17 \mathrm{a}$ & $0.12 b$ & $0.28 \mathrm{a}$ & $0.08 \mathrm{a}$ & $0.13 b$ & $0.28 \mathrm{a}$ & $0.16 b$ & $0.31 \mathrm{a}$ & $0.28 \mathrm{a}$ & $0.17 \mathrm{a}$ \\
\hline
\end{tabular}

$\mathrm{T} 1=0.7 \times 1.1 \mathrm{~m}$ (monocropped scarlet eggplant); $\mathrm{T} 2=0.7 \times 1.5 \mathrm{~m}$ ( 4 rows of chicory); $\mathrm{T} 3=0.7 \times 1.1 \mathrm{~m}(3$ rows of chicory $) ; \mathrm{T} 4=0.7 \times 1.3 \mathrm{~m}(4$ rows of chicory); $\mathrm{T} 5=0.7 \times 1.3 \mathrm{~m}$ ( 3 rows of chicory). Averages folled by the same lowcase letter in the column do not differ statistically among each other by Tukey test at $5 \%$.

Table 2. Comparison of averages for number of chicory leaves (units), unfolding of spacings between rows for each harvest under intercropped cultivation for scarlet eggplant crop. Alegre, IFES, 2018.

\begin{tabular}{|c|c|c|c|c|c|c|c|c|c|c|c|c|}
\hline \multirow{2}{*}{ Treatments } & \multicolumn{12}{|c|}{ Harvests } \\
\hline & $1^{\text {st }}$ & $2^{\text {nd }}$ & $3^{\text {rd }}$ & $4^{\text {th }}$ & $5^{\text {th }}$ & $6^{\text {th }}$ & $7^{\text {th }}$ & $8^{\text {th }}$ & $9^{\text {th }}$ & $10^{\text {th }}$ & $11^{\text {th }}$ & $12^{\text {th }}$ \\
\hline 2 & $4.20 \mathrm{a}$ & $4.50 \mathrm{a}$ & $3.05 \mathrm{a}$ & $2.75 b$ & $3.85 \mathrm{bc}$ & $2.80 \mathrm{~b}$ & $3.60 \mathrm{~b}$ & $4.90 \mathrm{bc}$ & $4.05 \mathrm{~b}$ & $4.20 \mathrm{~b}$ & $3.00 \mathrm{~b}$ & $2.80 \mathrm{~b}$ \\
\hline 3 & $3.50 \mathrm{a}$ & $3.85 \mathrm{a}$ & $2.75 \mathrm{a}$ & $3.35 \mathrm{ab}$ & $3.50 \mathrm{c}$ & $2.30 \mathrm{~b}$ & $3.55 \mathrm{~b}$ & $3.95 \mathrm{c}$ & $3.35 \mathrm{~b}$ & $3.75 b$ & $2.10 \mathrm{~b}$ & $2.55 \mathrm{~b}$ \\
\hline 4 & $4.45 a$ & $3.85 \mathrm{a}$ & $2.95 \mathrm{a}$ & $3.75 \mathrm{ab}$ & $5.70 \mathrm{a}$ & $2.80 \mathrm{~b}$ & $4.20 \mathrm{ab}$ & $3.75 \mathrm{c}$ & $3.65 b$ & $3.70 \mathrm{~b}$ & $2.60 \mathrm{~b}$ & $2.65 b$ \\
\hline 5 & $3.95 \mathrm{a}$ & $3.75 \mathrm{a}$ & $3.10 \mathrm{a}$ & $3.40 \mathrm{ab}$ & $5.15 \mathrm{ab}$ & $2.35 b$ & $3.85 \mathrm{~b}$ & $4.00 \mathrm{c}$ & $3.45 \mathrm{~b}$ & $4.65 b$ & $2.55 \mathrm{~b}$ & $2.70 \mathrm{~b}$ \\
\hline 6 & $3.50 \mathrm{a}$ & $4.65 \mathrm{a}$ & $3.60 \mathrm{a}$ & $4.55 \mathrm{a}$ & $4.65 \mathrm{abc}$ & $5.35 \mathrm{a}$ & $5.40 \mathrm{a}$ & $6.25 \mathrm{ab}$ & $5.55 \mathrm{a}$ & $6.25 \mathrm{a}$ & $3.40 \mathrm{~b}$ & $4.75 \mathrm{a}$ \\
\hline 7 & $3.60 \mathrm{a}$ & $4.30 \mathrm{a}$ & $3.60 \mathrm{a}$ & $4.40 \mathrm{a}$ & $4.45 \mathrm{abc}$ & $4.90 \mathrm{a}$ & $5.55 \mathrm{a}$ & $6.70 \mathrm{a}$ & $6.25 \mathrm{a}$ & $7.40 \mathrm{a}$ & $5.10 \mathrm{a}$ & $6.05 \mathrm{a}$ \\
\hline
\end{tabular}

$\mathrm{T} 2=0.2 \times 0.2 \mathrm{~m}$ ( 4 rows of chicory); $\mathrm{T} 3=0.2 \times 0.2 \mathrm{~m}$ ( 3 rows of chicory); $\mathrm{T} 4=0.2 \times 0.2 \mathrm{~m}$ ( 4 rows of chicory); $\mathrm{T} 5=0.2 \times 0.2 \mathrm{~m}(3$ rows of chicory); $\mathrm{T} 6=0.2 \times 0.1 \times 0.4 \mathrm{~m}$ (monocropped chicory); $\mathrm{T} 7=0.2 \mathrm{x} 0.3 \mathrm{~m}$ (monocropped chicory). Averages followed by the same lowcase letter in the column do not differ statistically among each other by Tukey test at $5 \%$. 
Table 3. Regression analysis for fresh mass scarlet eggplant $(\mathrm{kg} / \mathrm{pl})$ and number of chicory leaves (units) with unfolding of harvests within each level of spacing for both crops under intercropping system. Alegre, IFES, 2018.

\begin{tabular}{|c|c|c|c|c|c|c|c|}
\hline \multicolumn{8}{|c|}{ Scarlet eggplant } \\
\hline & Model & Parameter & Estimates & Standard error & $\mathbf{t}_{\mathrm{c}}$ & p value & $\mathbf{R}^{2}(\%)$ \\
\hline \multirow{9}{*}{$\mathrm{T} 2$} & \multirow{2}{*}{ Linear } & $\beta_{0}$ & 0.1654 & 0.0285 & 5.7976 & $0 *$ & \multirow{2}{*}{0.254377} \\
\hline & & $\beta_{1}$ & 0.0109 & 0.0030 & 3.6907 & $0.0003 *$ & \\
\hline & \multirow{3}{*}{ Quadratic } & $\beta_{0}$ & 0.0256 & 0.0465 & 0.5517 & $0.5818 \mathrm{~ns}$ & \multirow{3}{*}{0.525010} \\
\hline & & $\beta_{1}$ & 0.0575 & 0.0126 & 4.5658 & $0.00001 *$ & \\
\hline & & $\beta_{2}$ & -0.0027 & 0.0007 & -3.8068 & $0.0002 *$ & \\
\hline & \multirow{4}{*}{ Cubic } & $\beta_{0}$ & -0.0337 & 0.0701 & -0.4799 & $0.6318 \mathrm{~ns}$ & \multirow{4}{*}{0.548833} \\
\hline & & $\beta_{1}$ & 0.0939 & 0.0346 & 2.7110 & $0.0073 *$ & \\
\hline & & $\beta_{2}$ & -0.0079 & 0.0047 & -1.7036 & $0.0900 \mathrm{~ns}$ & \\
\hline & & $\beta_{3}$ & 0.0002 & 0.0002 & 1.1294 & $0.2601 \mathrm{~ns}$ & \\
\hline \multirow{9}{*}{$\mathrm{T} 3$} & \multirow{2}{*}{ Linear } & $\beta_{0}$ & 0.1865 & 0.0285 & 6.5363 & $0 *$ & \multirow{2}{*}{0.087189} \\
\hline & & $\beta_{1}$ & 0.0062 & 0.0030 & 2.1163 & $0.0356^{*}$ & \\
\hline & \multirow{3}{*}{ Quadratic } & $\beta_{0}$ & 0.0395 & 0.0465 & 0.8497 & $0.3965 \mathrm{~ns}$ & \multirow{3}{*}{0.399214} \\
\hline & & $\beta_{1}$ & 0.0552 & 0.0126 & 4.3879 & $0.00002 *$ & \\
\hline & & $\beta_{2}$ & -0.0029 & 0.0007 & -4.0034 & $0.0001 *$ & \\
\hline & \multirow{4}{*}{ Cubic } & $\beta_{0}$ & 0.0508 & 0.0701 & 0.7238 & $0.4700 \mathrm{~ns}$ & \multirow{4}{*}{0.400110} \\
\hline & & $\beta_{1}$ & 0.0483 & 0.0346 & 1.3943 & $0.1648 \mathrm{~ns}$ & \\
\hline & & $\beta_{2}$ & -0.0019 & 0.0047 & -0.4062 & $0.6850 \mathrm{~ns}$ & \\
\hline & & $\beta_{3}$ & -0.00004 & 0.0002 & -0.2145 & $0.8304 \mathrm{~ns}$ & \\
\hline \multirow{9}{*}{$\mathrm{T} 4$} & \multirow{2}{*}{ Linear } & $\beta_{0}$ & 0.2170 & 0.0285 & 7.6068 & $0^{*}$ & \multirow{2}{*}{0.109943} \\
\hline & & $\beta_{1}$ & 0.0093 & 0.0030 & 3.1441 & $0.0019 *$ & \\
\hline & \multirow{3}{*}{ Quadratic } & $\beta_{0}$ & 0.1365 & 0.0465 & 2.9362 & $0.0037^{*}$ & \multirow{3}{*}{0.163422} \\
\hline & & $\beta_{1}$ & 0.0361 & 0.0126 & 2.8687 & $0.0046^{*}$ & \\
\hline & & $\beta_{2}$ & -0.0016 & 0.0007 & -2.1928 & $0.0295^{*}$ & \\
\hline & \multirow{4}{*}{ Cubic } & $\beta_{0}$ & -0.0149 & 0.0701 & -0.2123 & $0.8321 \mathrm{~ns}$ & \\
\hline & & $\beta_{1}$ & 0.1292 & 0.0346 & 3.7283 & $0.0002 *$ & 0255873 \\
\hline & & $\beta_{2}$ & -0.0149 & 0.0047 & -3.1871 & $0.0017^{*}$ & $0.2558 / 3$ \\
\hline & & $\beta_{3}$ & 0.0005 & 0.0002 & 2.8831 & $0.0044^{*}$ & \\
\hline & Linear & $\beta_{0}$ & 0.2930 & 0.0285 & 10.2692 & $0^{*}$ & 0000104 \\
\hline & Linedr & $\beta_{1 \ldots}$ & 0.0003 & 0.0030 & 0.0967 & $0.9231 \mathrm{~ns}$ & 0.000104 \\
\hline & & $\beta_{0}$ & 0.1731 & 0.0465 & 3.7240 & $0.0003^{*}$ & \\
\hline & Quadratic & $\beta_{1}$ & 0.0402 & 0.0126 & 3.1959 & $0.0016^{*}$ & 0.118671 \\
\hline T5 & & $\beta_{2}$ & -0.0023 & 0.0007 & -3.2641 & $0.0013^{*}$ & \\
\hline & & $\beta_{0}$ & 0.0648 & 0.0701 & 0.9239 & $0.3567 \mathrm{~ns}$ & \\
\hline & & $\beta_{1}$ & 0.1068 & 0.0346 & 3.0832 & $0.0023 *$ & \\
\hline & Cubic & $\beta_{2}$ & -0.0119 & 0.0047 & -2.5424 & $0.0118^{*}$ & 0.166039 \\
\hline & & $\beta_{3}$ & 0.0004 & 0.0002 & 2.0631 & $0.0404^{*}$ & \\
\hline & & & & cory & & & \\
\hline & I inear & $\beta_{0}$ & 3.8780 & 0.2053 & 18.8869 & $0^{*}$ & 0030851 \\
\hline & Linear & $\beta_{1}$ & -0.0364 & 0.0279 & -1.3034 & $0.1927 \mathrm{~ns}$ & 0.030851 \\
\hline & & $\beta_{0}$ & 3.7750 & 0.3448 & 10.9482 & $0^{*}$ & \\
\hline & Quadratic & $\beta_{1}$ & 0.0078 & 0.1220 & 0.0639 & $0.9491 \mathrm{~ns}$ & 0.033363 \\
\hline $\mathrm{T} 2$ & & $\beta_{2}$ & -0.0034 & 0.0091 & -0.3720 & $0.7100 \mathrm{~ns}$ & \\
\hline & & $\beta_{0}$ & 5.9652 & 0.5458 & 10.9286 & $0 *$ & \\
\hline & Cubic & $\beta_{1}$ & -1.6850 & 0.3490 & -4.8275 & $0 *$ & 0519885 \\
\hline & Cuoir & $\beta_{2}$ & 0.3095 & 0.0611 & 5.0624 & $0 *$ & 0.319000 \\
\hline & & $\beta_{3}$ & -0.0160 & 0.0031 & -5.1761 & $0 *$ & \\
\hline
\end{tabular}


Table 3. continuation

\begin{tabular}{|c|c|c|c|c|c|c|c|}
\hline \multicolumn{8}{|c|}{ Chicory } \\
\hline & Model & Parameter & Estimates & Standard error & $\mathbf{t}_{\mathbf{c}}$ & p value & $\mathrm{R}^{2}(\%)$ \\
\hline \multirow{9}{*}{$\mathrm{T} 3$} & \multirow{2}{*}{ Linear } & $\beta_{0}$ & 3.5856 & 0.2053 & 17.4628 & $0^{*}$ & \multirow{2}{*}{0.112580} \\
\hline & & $\beta_{1}$ & -0.0580 & 0.0279 & -2.0805 & $0.0377 *$ & \\
\hline & \multirow{3}{*}{ Quadratic } & $\beta_{0}$ & 3.2318 & 0.3448 & 9.3729 & $0 *$ & \multirow{3}{*}{0.155009} \\
\hline & & $\beta_{1}$ & 0.0936 & 0.1220 & 0.7674 & $0.4430 \mathrm{~ns}$ & \\
\hline & & $\beta_{2}$ & -0.0117 & 0.0091 & -1.2772 & $0.2018 \mathrm{~ns}$ & \\
\hline & \multirow{4}{*}{ Cubic } & $\beta_{0}$ & 4.3702 & 0.5458 & 8.0065 & $0^{*}$ & \multirow{4}{*}{0.343275} \\
\hline & & $\beta_{1}$ & -0.7863 & 0.3490 & -2.2527 & $0.0245^{*}$ & \\
\hline & & $\beta_{2}$ & 0.1510 & 0.0611 & 2.4694 & $0.0137^{*}$ & \\
\hline & & $\beta_{3}$ & -0.0083 & 0.0031 & -2.6904 & $0.0072 *$ & \\
\hline \multirow{9}{*}{$\mathrm{T} 4$} & \multirow{2}{*}{ Linear } & $\beta_{0}$ & 4.3697 & 0.2053 & 21.2815 & $0^{*}$ & \multirow{2}{*}{0.194085} \\
\hline & & $\beta_{1}$ & -0.1075 & 0.0279 & -3.8539 & $0.0001 *$ & \\
\hline & \multirow{3}{*}{ Quadratic } & $\beta_{0}$ & 3.7148 & 0.3448 & 10.7735 & $0^{*}$ & \multirow{3}{*}{0.267134} \\
\hline & & $\beta_{1}$ & 0.1732 & 0.1220 & 1.4200 & $0.1559 \mathrm{~ns}$ & \\
\hline & & $\beta_{2}$ & -0.0216 & 0.0091 & -2.3643 & $0.0182 *$ & \\
\hline & \multirow{4}{*}{ Cubic } & $\beta_{0}$ & 4.4510 & 0.5458 & 8.1546 & $0^{*}$ & \multirow{4}{*}{0.306697} \\
\hline & & $\beta_{1}$ & -0.3959 & 0.3490 & -1.1342 & $0.2570 \mathrm{~ns}$ & \\
\hline & & $\beta_{2}$ & 0.0836 & 0.0611 & 1.3673 & $0.1718 \mathrm{~ns}$ & \\
\hline & & $\beta_{3}$ & -0.0054 & 0.0031 & -1.7400 & $0.0821 \mathrm{~ns}$ & \\
\hline \multirow{9}{*}{ T5 } & \multirow{2}{*}{ Linear } & $\beta_{0}$ & 3.9250 & 0.2053 & 19.1157 & $0^{*}$ & \multirow{2}{*}{0.054180} \\
\hline & & $\beta_{1}$ & -0.0538 & 0.0279 & -1.9301 & $0.0538 \mathrm{~ns}$ & \\
\hline & \multirow{3}{*}{ Quadratic } & $\beta_{0}$ & 3.4114 & 0.3448 & 9.8936 & $0^{*}$ & \multirow{3}{*}{0.104189} \\
\hline & & $\beta_{1}$ & 0.1663 & 0.1220 & 1.3635 & $0.1730 \mathrm{~ns}$ & \\
\hline & & $\beta_{2}$ & -0.0169 & 0.0091 & -1.8543 & $0.0640 \mathrm{~ns}$ & \\
\hline & \multirow{4}{*}{ Cubic } & $\beta_{0}$ & 4.4737 & 0.5458 & 8.1962 & $0 *$ & \multirow{4}{*}{0.195875} \\
\hline & & $\beta_{1}$ & -0.6548 & 0.3490 & -1.8761 & $0.0609 \mathrm{~ns}$ & \\
\hline & & $\beta_{2}$ & 0.1348 & 0.0611 & 2.2056 & $0.0276^{*}$ & \\
\hline & & $\beta_{3}$ & -0.0078 & 0.0031 & -2.5107 & $0.0122 *$ & \\
\hline & J inear & $\beta_{0}$ & 4.1227 & 0.2053 & 20.0787 & $0^{*}$ & \\
\hline & Linear & $\beta_{1}$ & 0.1080 & 0.0279 & 3.8727 & $0.0001 *$ & 0.157143 \\
\hline & & $\beta_{0}$ & 2.6136 & 0.3448 & 7.5800 & $0^{*}$ & \\
\hline & Quadratic & $\beta_{1}$ & 0.7548 & 0.1220 & 6.1894 & $0 *$ & 0.468126 \\
\hline T6 & & $\beta_{2}$ & -0.0498 & 0.0091 & -5.4479 & $0 *$ & \\
\hline & & $\beta_{0}$ & 3.7874 & 0.5458 & 6.9387 & $0^{*}$ & \\
\hline & Cuhio & $\beta_{1}$ & -0.1524 & 0.3490 & -0.4366 & $0.6625 \mathrm{~ns}$ & \\
\hline & Cubic & $\beta_{2}$ & 0.1179 & 0.0611 & 1.9290 & $0.0540 \mathrm{~ns}$ & 0.548751 \\
\hline & & $\beta_{3}$ & -0.0086 & 0.0031 & -2.7739 & $0.0056^{*}$ & \\
\hline & Linear & $\beta_{0}$ & 3.4326 & 0.2053 & 16.7175 & $0^{*}$ & 0643755 \\
\hline & Linear & $\beta_{1}$ & 0.2706 & 0.0279 & 9.7004 & $0 *$ & $0.643 / 55$ \\
\hline & & $\beta_{0}$ & 2.7250 & 0.3448 & 7.9030 & $0^{*}$ & \\
\hline & Quadratic & $\beta_{1}$ & 0.5739 & 0.1220 & 4.7058 & $0 *$ & 0.688394 \\
\hline $\mathrm{T} 7$ & & $\beta_{2}$ & -0.0233 & 0.0091 & -2.5544 & $0.0108^{*}$ & \\
\hline & & $\beta_{0}$ & 4.4025 & 0.5458 & 8.0658 & $0^{*}$ & \\
\hline & & $\beta_{1}$ & -0.7227 & 0.3490 & -2.0705 & $0.0386^{*}$ & \\
\hline & Cubic & $\beta_{2}$ & 0.2163 & 0.0611 & 3.5385 & $0.0004^{*}$ & 0.795924 \\
\hline & & $\beta_{3}$ & $-0,0123$ & 0,0031 & $-3,9646$ & $0,0001^{*}$ & \\
\hline
\end{tabular}

Scarlet eggplant: $\mathrm{T} 2=0.7 \times 1.5 \mathrm{~m}$ ( 4 rows of chicory); $\mathrm{T} 3=0.7 \times 1.1 \mathrm{~m}$ ( 3 rows of chicory); $\mathrm{T} 4=0.7 \times 1.3 \mathrm{~m}(4 \mathrm{rows}$ of chicory); $5=0.7 \times 1.3$ $\mathrm{m}$ ( 3 rows of chicory). Chicory: $\mathrm{T} 2=0.2 \times 0.2 \mathrm{~m}$ ( 4 rows of chicory); $\mathrm{T} 3=0.2 \times 0.2 \mathrm{~m}$ ( 3 rows of chicory); $\mathrm{T} 4=0.2 \times 0.2 \mathrm{~m}(4$ rows of chicory); $\mathrm{T} 5=0.2 \times 0.2 \mathrm{~m}$ ( 3 rows of chicory); $\mathrm{T} 6=0.2 \times 0.1 \times 0.4 \mathrm{~m}$ (monocropped chicory); $\mathrm{T} 7=0.2 \times 0.3 \mathrm{~m}$ (monocropped chicory). 
Table 4. The Area Equivalence Index (IEA) for total production of scarlet eggplant $(\mathrm{kg} / \mathrm{pl})$ and chicory $\left(\mathrm{n}^{\circ} \mathrm{f} / \mathrm{pl}\right)$ under intercropping system. Alegre, IFES, 2018.

\begin{tabular}{ccccc}
\hline Treatments & Scarlet eggplant & Chicory & IEA 1 & IEA 2 \\
\hline Intercropping & $0.7 \times 1.5 \mathrm{~m}$ & $0.2 \times 0.2 \mathrm{~m}$ (4 rows) & 1.83 & 1.94 \\
Intercropping & $0.7 \times 1.1 \mathrm{~m}$ & $0.2 \times 0.2 \mathrm{~m}$ (3 rows) & 1.81 & 1.91 \\
Intercropping & $0.7 \times 1.3 \mathrm{~m}$ & $0.2 \times 0.2 \mathrm{~m}$ (4 rows) & 1.86 & 1.97 \\
Intercropping & $0.7 \times 1.3 \mathrm{~m}$ & $0.2 \times 0.2 \mathrm{~m}$ (3 rows) & 1.63 & 1.74 \\
\hline
\end{tabular}

IEA $1=$ using monocropped chicory in spacing between double rows $0.2 \times 0.1 \times 0.4 \mathrm{~m}$; IEA $2=$ using monocropped chicory in spacing $0.2 \times 0.3 \mathrm{~m}$.

other spacings for scarlet eggplat crop in some harvests, the same spacing is viable due to the increase in the number of plants per area, considering that more dense plants obtain a better supply of water and nitrogen (Correa et al., 2014). Furthermore, smaller spacings encourage plants to compete for light, while reducing the loss of essential elements due to erosion (Nomura et al., 2018).

Using the harvest unfolding in each spacing, the authors observed that no adjustment in almost all unfoldings was observed (Table 3). The linear, quadratic and cubic group are not in $\mathrm{T} 1$, spacing $0.7 \times 1 \mathrm{~m}$, since no significant difference among harvests was noticed. For chicory, significant difference was observed in all harvests, and for that reason, the linear, quadratic and cubic group shows six times according to the order of treatments.

The Area Equivalence Index (IEA) was used to evaluate land-use efficiency, since this ratio is related to the land area required in monocropping system, aiming to obtain the same production when cultivated under intercropping system (Vieira, 1984). Also, according to Vieira (1984), for being efficient, the intercropped cultivation needs to show IEA superior to 1.0.

In this experiment, we observed that intercropping between scarlet eggplant and chicory provided values superior to 1.0 (Table 4). The increase in productivity can be obtained with greater populations, taking into consideration the size and qualitative traits, as these traits may restrict marketing (Sala et al., 2004 ).

Generally, monocropped chicory was more efficient when unfolding the spacings for each harvest through the average test. Even if it is not possible to recommend a better intercropping between these crops, it is possible to say that farmers will have weekly harvests reducing cost and area. Monocropped scarlet eggplant was as efficient as the intercroppings $0.7 \times 1.5 \mathrm{~m}$ and $0.7 \times 1.3$ $\mathrm{m}$, since they show higher averages in some harvests.

\section{REFERENCES}

BRITO, AU; PUIATTI, M; CECON, PR; FINGER, FL; MENDES, TDC. 2017. Viabilidade agroeconômica dos consórcios taro com brócolis, couve-chinesa, berinjela, jiló, pimentão e maxixe. Revista Brasileira de Ciências Agrárias 12: 296-302. http://dx.doi. org/10.5039/agraria.v12i3a5452

CECÍLIO FILHO, AB; COSTA, CC; REZENDE, BLA; LEEUWEN, R. 2008. Viabilidade produtiva e econômica do consórcio entre chicória e rúcula em função da época de plantio. Horticultura Brasileira 26: 316-320. https:// doi. org/10.1590/S0102-05362008000300005.

CORREA CV; CARDOSO AII; SOUZA LG; ANTUNES WLP; MAGOLBO LA. 2014. Produção de beterraba em função do espaçamento. Horticultura Brasileira 32: 111-114.

COSTA, CC; CECÍLIO FILHO, AB; REZENDE, BLA; BARBOSA, JC; GRANGEIRO, LC. 2007. Viabilidade agronômica do consórcio de alface e rúcula, em duas épocas de cultivo. Horticultura Brasileira 25: 34-40. https://doi. org/10.1590/S0102-05362007000100008.
EMBRAPA - Empresa Brasileira de Pesquisa Agropecuária. 1999. Sistema Brasileiro de Classificação de Solos. ed. Embrapa. Rio de Janeiro: Embrapa, 412p.

FRANCO, G. 1987. Teor vitamínico dos alimentos Rio de Janeiro: José Olympio. 141p.

HEREDIA ZÁRATE, NA; VIEIRA, MC; GRACIANO, JD; GIULIANI, AR; HELMICH, MAND; GOMES, HE. 2009. Produção e renda bruta de quatro clones de taro cultivados em Dourados, Estado do Mato Grosso do Sul. Acta Scientiarum Agronomy 31: 301-305. https:// doi. org/10.4025/actasciagron.v31i2.479.

LIMA, JSS. 2008. Viabilidade agroeconômica de consórcios em faixas de cenoura e rúcula em bicultivo (Ph.D. Thesis).

LOPES, NF; LIMA, MGS. 2015. Fisiologia da produção. Viçosa: Editora UFV, 492p.

MINAMI, K; CARDOSO, AII; COSTA, F; DUARTE, FR. 1998. Efeito do espaçamento sobre a produção em rabanete. Bragantia 57: 169-173.

MONTEZANO, EM, PEIL, RMN. 2006. Sistemas de consórcio na produção de hortaliças. Current Agricultural Science and Technology 12(2).

NOMURA, M; CAVALCANTI,UR;VILARINHO, MS. 2018. Efeito do espaçamento no cultivo do repolho. Intercursos Revista Cientifica

OHSE, S; REZENDE, BLA; SILVEIRA, LS; OTTO, RF; CORTEZ, MG. 2012. Viabilidade agronômica de consórcios de brócolis e alface estabelecidos em diferentes épocas. Idesia 30: 29-37.

PAULA, PD; GUERRA, JGM; RIBEIRO, RLD; CESAR, MNZ; GUEDES, RE; POLIDORO, JC. 2009. Viabilidade agronômica de consórcios entre cebola e alface no sistema orgânico de produção. Horticultura Brasileira 27: 202-206. https://doi.org/10.1590/S010205362009000200014

PUIATTI, M; OLIVEIRA, NLC; CECON, PR; BHERING, AS. 2015. Consorciação de taro e crotalária manejada com corte rente ao solo e poda na altura do dossel. Ceres 62(3).https:// doi.org/10.1590/0034- 737X201562030007

PURQUERIO, LFV; DERANT, LAR; GOTO, R; VILLAS BOAS, RL. 2007. Effect of side dressing nitrogen fertilization and distance between plants on yield of rocket salad. Horticultura Brasileira 25: 464-470. https:// doi.org/10.1590/S0102-05362007000300028

REZENDE, BLA. 2016. Consórcios de pepino e alface em cultivo protegido: viabilidade agroeconômica. Jaboticabal: UNESP. 163p. (Ph.D. Thesis). http://hdl.handle. net/11449/105269.

SALA, FC; ROSSI, F; FABRI, EG; RONDINO, E; MINAMI, K; COSTA, C. 2004. Caracterização varietal de rúcula. In: Congresso Brasileiro de Olericultura. Vol. 22. Julho.

VIEIRA, C. 1984. Índice de equivalência de área. Informe Agropecuário, 10: 12-13. 